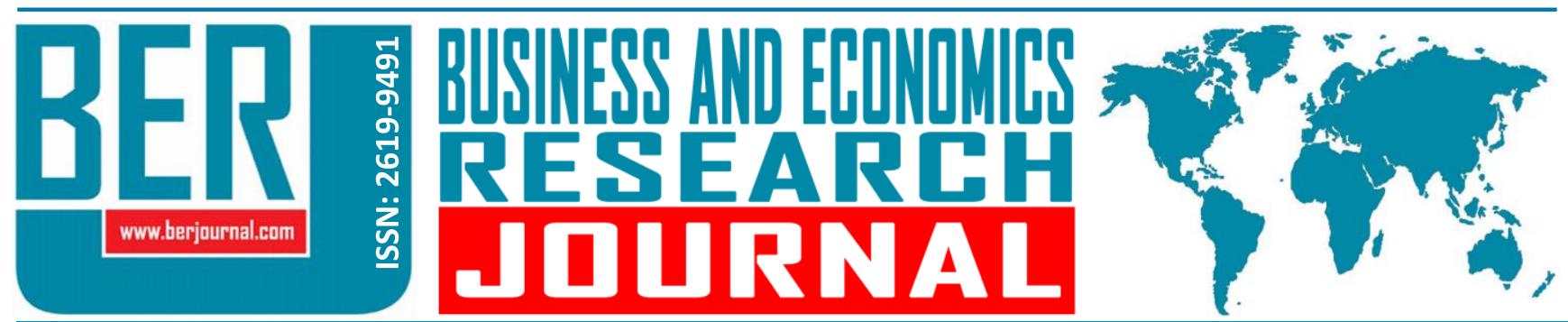

Business and Economics Research Journal Vol. 10, No. 5, 2019, pp. 1127-1142 doi: 10.20409/berj.2019.225

\title{
Katılım Bankacılığı Reklamlarında İçerik Analizi ${ }^{1}$
}

\section{Fatma Gul Bilginer Ozsaatci ${ }^{\mathrm{a}}$}

Öz: Günümüzün rekabet yoğun piyasalarında işletmelerin hedef kitleye hitap etmelerinde kullanılan reklamlar finansal ürünlerin tanıtımında ve pazarlamasında da etkili olarak kullanılmaktadır. İ̧leyiş ve hitap edilen tüketici kitlesi açısından farklılaşan katılım bankaları da TV reklamlarından faydalanmaktadır. Katılım bankalarının mevcut özellikleri dolayısıyla reklamlarında doğru mesajı vermeleri önemlidir. Reklamlarda tekrar eden söz ve kelimeler tüketicinin zihninde kalıcılık sağlayacağı için verilmek istenen mesaja en uygun kelimelerin seçilmesi önem arz etmektedir. Bu çalışmanın amacı finansal sistem içerisinde farklı işleyişe sahip katılım bankaları reklamlarının tüketiciye vermek istedikleri mesajların analiz edilmesidir. Bu amaçla Türkiyede kurulduğu günden itibaren katılım bankası olarak faaliyetlerini yürütüp aktif olarak TV reklamlarından faydalanan iki katılım bankasının reklamları MAXQDA paket programı ile analiz edilmiştir. Analiz sonucunda oluşan kodlama sayısı 283, kod sayısı 90 ve tema sayısı 62 olup temalar; örgüte ve çalışma prensibine ilişkin unsurlar, ekonomik ve finansal unsurlar, sosyal ilişki ve iç motivasyon unsurları, kültürel değer unsurları, dini unsurlar ve evrensel değer unsurları altında toplanmıştır.

\section{Content Analysis in Participation Banking Advertisements}

Abstract: In today's highly competitive markets, advertisements that are used to address the target audience are used effectively in the promotion and marketing of financial products. Participation banks, which differ in terms of operation and appealing consumer mass, also benefit from TV advertisements. It is important that participation banks give the correct message in their advertisements due to their current characteristics. Since repetitive words and words in advertisements will provide permanence in the mind of the consumer, it is important to select the most appropriate words for the message to be given. The aim of this study is to analyze the messages of the participation banks' advertisements with different functions in the financial system. For this purpose, the ads of two participation banks carrying out their activities in Turkey since their foundation as participation banks and benefiting from TV ads have been actively analyzed by MAXQDA package program. As a result of the analysis, the gathered number of code is 283, the number of code is 90 and the number of themes is 62 and themes are grouped under organizational and working principles, economic and financial elements, social relations and internal motivation elements, cultural value elements, religious elements, and universal value elements.

Anahtar Sözcükler: Katılım Bankacılı̆̆ı, Reklam, iç̧erik Analizi

JEL: G20, M37

$\begin{array}{ll}\text { Geliş } & : 24 \text { Nisan } 2019 \\ \text { Düzeltme } & : 20 \text { Haziran } 2019 \\ \text { Kabul } & : 21 \text { Ağustos } 2019 \\ \text { Tür } & : \text { Araştırma }\end{array}$

Keywords: Participation Banking, Advertising, Content Analysis

JEL: G20, M37

Received : 24 April 2019

Revised : 20 June 2019

Accepted : 21 August 2019

Type : Research 


\section{Giriş}

Finansal sistemin en önemli aktörlerinden biri olan bankalar sistemin işleyişinde ve gelişmesinde büyük bir etkiye sahiptir. Bankalar ülke ekonomilerinin işleyişinde, sermaye birikiminde, tasarruf sahiplerinin yatırımlarını ekonomik sistemde değerlendirmelerinde rol oynamaktadır. Bankacılık sisteminin işleyişi finansal sistemde fonların dolaşıma girmesini sağlamıştır. Finansal sistemde faaliyet gösteren bankalar mevduat bankaları, kalkınma ve katıım bankaları olarak ayrılmaktadır. Dini hassasiyetleri olan yatırımcıların bir kısmının tasarruflarını finansal sisteme sokmamalarından dolayı faizsiz sistemle dini prensiplere dayalı olarak çalışan katıım bankacılığı ortaya çıkmıştır. Katıım bankaları finansal sisteme bu tasarrufları da katmak amacıyla faaliyet göstermeye başlamışlardır. Günümüz pazarlarında işletme büyüklüğü ve faaliyet sektörü farketmeksizin işletmeler çok yoğun rekbet içindedirler. Yoğun rekabetin yaşandığı pazarlarda rakipler arasından sıyrılmada etkili olan araçlardan biri de reklamlardır. Temel amacı, işletmelerin bilinirliğinin sağlanması ve sunulan ürün veya hizmetin farklılı̆ının ortaya konması olan reklamların finansal ürün veya hizmetlerin pazarlamasında kullanılması fark yaratmaktır. Katılım bankaları reklamları da hem var olan müşteri gruplarına hitap etmede hem de işleyişlerini ve farklııklarını farklı tüketici gruplarına anlatmada önem arz etmektedir. Özellikle televizyon sadece kâğıt üzerinde kalan gazete veya dergilere kıyasla gerçek dünyaya yakın olmasından ve reklamların gün içerisinde sürekli akmasından dolayı insanları etkilemede daha güçlüdür. Katılım bankaları da mevcut özellikleri dolayısıyla yapılacak TV reklamları stratejilerini doğru belirlemelidir. Geleneksel bankacılık sisteminden farklılaşan yönlerin iyi vurgulanması için pazarlama faaliyetleri ve reklamlar tüketici kitlesini bilgilendirmeye yönelik olmalıdır. Bundan dolayı hazırlanacak reklamların doğru mesajı vermesi gerekmektedir. Reklamlarda tekrar eden söz ve kelimeler tüketicinin zihninde kalıclık sağlayacağı için verilmek istenen mesaja en uygun kelimelerin seçilmesi önem arz etmektedir. Bu doğrultuda bu çalışmada işleyiş açısından farklılaşan katılım bankacılığı reklamlarında tekrar eden kelimelerin ve verilmek istenen mesajların belirlenmesi amaçlanmıştır. Bu amaç doğrultusunda çalışmada aşağıda yer alan araştırma sorularına cevap aranmıştır:

- Katıım bankaları reklamlarında öne çıkan temel konular nelerdir?

- Katılım bankaları reklamlarında en fazla vurgulanan kelimeler nelerdir?

- Katılım bankaları reklamlarında en fazla hangi tür bilgiler yer almakta ve tekrarlanmaktadır?

Yoğun rekabet ortamında işletmelerin kendilerini anlatmak ve farklılıklarını ortaya koymak için başvurdukları iletişim araçlarının başında TV reklamları gelmektedir. Ilggili literatür incelendiğinde katılım bankacılığının farkındalığının oluşturulmasında ve sürdürülmesinde reklamlar önemli bir unsur olarak karşımıza çıkmaktadır. Katılım bankacılığı reklamlarına ve yayınlanan reklamların içeriğinin tespit edimesine yönelik herhangi bir çalışmaya rastlanmamış olması çalışmayı özgün kılmaktadır. Bankalar bu reklamlara yüksek bütçeler ayırmaktadır. Bu nedenle yapılan reklamlarda verilen mesajların tanıtıcı olması ve farkındalık oluşturucu olması önemlidir. Yanlış reklam kampanyaları kurumlara milyonlarca lira maliyete neden olmaktadır. Reklamlarda verilen mesajların analizi bu bakımdan önem arz etmektedir. Bunun yanında bu çalışmada reklamların analiz edilerek ilgililerin konuya ilişkin bilgilendirilmesi ve reklamlarda verilmek istenen mesajların belirli kategoriler altında toplanıyor olması çalışmanın önemini arttırmaktadır. Elde edilen sonuçlar katılım bankacılığı reklamlarının analizine yönelik yapılacak bilimsel çalışmalara bir altyapı oluşturacağından önemlidir. Elde edilen sonuçların gelecekte yapılacak reklam içeriklerinin belirlenmesinde yol gösterici olacağı düşünülmektedir.

\section{Kuramsal Çerçeve}

\subsection{Katılım Bankacılığı}

Katılım bankacılığı dünyada katılım bankacılığı ya da faizsiz bankacılık olarak adlandırımaktadır. Faizsiz bankacılık ve İslam bankacılığının eksiklikleri eleştirilmiş bu nedenle yeni bir kavram anlayışına gidilmiş ve katılım bankacılığı kavramı ortaya çıkmıştır (Darçın, 2007). Türkiye'de bu kavram ilk olarak 2005 yılında "özel finans kurumları" adının değiştirilerek "katılım bankacılığı" olarak kabul edilmesiyle kullanılmaya başlanmıştır (Özkan, 2012: 25). Faizsiz bankacılık, yani katılım bankacılığı, isminden de anlaşıldığı gibi faiz 
sistemi olmadan işlemekte ve çalışma prensipleri de İslami kurallara dayanmaktadır. Dini hassasiyetlerinden dolayı kişilerin faizden sakınması durumunda katıım bankaları devreye girmekte ve faizden sakınan kişilerin ellerinde bulunan fonlarının bankaya yani finansal sisteme sokulmasını sağlamaktadır. Sonuç olarak; bankaların yaptığı çoğu bankacılık faaliyetlerini yürüten ve dolayısıyla da aynı ekonomik koşullarda onlarla rekabet eden katılım bankalarının mevcut mali sistem içinde hedefledikleri sonuçlara daha kolay ulaşabilmeleri için, farklı bankacılık yönlerini ve uygulamalarını sürekli olarak sürdürmeleri ve bu farklılıklarını hedef kitlelerine doğru bir şekilde iletmeleri gerekir. Amerikan Pazarlama Birliği'nin "müssteriler, alııılar, paydaşlar ve toplumun bütünü için değer ifade eden önerilerin geliştirilmesi, iletişimi, ulaştırılması ve değişimi için bir faaliyet, bir dizi kurum ve süreç" olarak tanımladığı pazarlama kavramı katılım bankalarının müşterilerine hizmet ve değer önerileri sunması sürecini de kapsamaktadır. Bankalar sunacakları değer önerilerini pazarlama faaliyetlerini etkin şekilde kullanarak gerçekleştirebilirler.

Literatür incelendiğinde mevcut katılım bankası müşterilerinin müşteri memnuniyetini ölçmeye yönelik olan çalışmalar (Othman ve Owen, 2001; Amin ve Isa, 2008; Bilir ve Özgen, 2010; Khattak ve Ur Rehman, 2010; Yılmaz, 2010; Kaytancı, Ergeç ve Toprak, 2013; Şendoğdu, 2014; Hamzah, Ishak ve Nor, 2015), katılım bankasını tercih etme nedenlerini ölçmeye yönelik olan çalışmalar (Haron, Ahmad ve Planisek, 1994; Dusuki ve Abdullah, 2007; Al-Ajmi, Abo Hussain ve Al-Saleh vd, 2009; Awan ve Bukhari, 2011; Abduh ve Omar, 2012; Echchabi ve Aziz, 2012; Hasan, Subhani ve Osman, 2012; Özsoy, Görmez ve Mekik, 2013; Ramadan, 2013) ve her ikisini de birlikte incelemeye yönelik olan çalışmalara (Metawa ve Almossawi, 1998; Naser, Jamal ve Al-Khatib, 1999; Okumuş, 2005; Haque, Osman ve Ismail, 2009; Sarı, 2010; Okumuş ve Genç, 2013; Kader, Zakaria, Razali ve Abdullah, 2014) rastlanmaktadır. Ayrıca katılım bankacılığı farkındalığı ve reklamlarına ilişkin çalışmalara ilgili başlık altında yer verilmiştir.

\subsection{Hizmet Pazarlaması}

Grönroos (1990)'a göre hizmet; yapısı gereği imtiyazlı olup, tüketici, işletme personeli ve fiziki olanaklar ile sistemler arasında etkileşim oluşmasıyla birlikte tüketici sorunlarını çözen faaliyetler dizisidir. Hizmetlerin mallardan farklı özelliklerinin (üretildiği anda tüketilmesi, soyut olması, heterojen olması, standardizasyonunun olmaması) olması onların pazarlamasını zorlaştırmakta ve farklı pazarlama stratejilerinin kullanılmasını zorunlu kılmaktadır (Karafakıoğlu, 2012: 129).

Hizmet üreten işletme sayılarının büyük bir hızla artması bu alanda da rekabetin yoğunlaşmasına neden olmuştur. Rekabetin artması farklılaşmayı gerektirdiği için hizmet pazarlaması kavramı önem kazanmaya başlamıştır. Hizmet pazarlaması; çalışan, işletme ve müşteri olmak üzere üç ayrı boyuta sahiptir. Bu üç boyut arasında ise sırasıyla; çalışan-işletme arasında daha iyi hizmet vermek için oluşan içsel pazarlama faaliyetleri, müşteri-işletme arasında pazarlamanın $4 \mathrm{P}^{\prime}$ sini kullanarak klasik pazarlama faaliyetinin yerine getirilmesini sağlayan dışsal pazarlama faaliyetleri, çalışan-müşteri arasında ise tüketici ile sıkı bir bağ kurarak işletmeye rekabet avantajı sağlayan interaktif pazarlama faaliyetleri sürdürülmektedir (Amstrong ve Kotler, 2009: 254). Hizmet pazarlamasının bazı temel özellikleri şu şekilde sıralanabilir (Karaca, 2006: 6):

- Tüketicilerin istek ve ihtiyaçlarını belirleyerek buna yönelik hizmetlerin sunulması,

- Pazarlama faaliyetlerinin sürekliliğinin olması,

- Hizmet Pazarlaması sürecinin birbirini takip eden ve sistematiklik gerektiren basamaklardan oluşması,

- Hizmet Pazarlaması araştırmalarında sürekliliğin olması,

- Hizmet işletmeleri arasındaki işbirliğinin artması,

- Müşteri memnuniyetinde kaliteye önem verilmesi,

- Pazarlama faaliyetlerinin etkinliğinin ölçülmesinin zor olması. 


\subsection{Banka Pazarlaması}

Yıllar içerisinde rekabetin artması ve finansal kuruluşların gelişmesi bankaların da pazarlama faaliyetlerine yönelmelerine neden olmuştur. Önceleri bankacılık faaliyetleri sadece banka içerisinde sürdürülürken rekabetin artması ile bankacılar pazara yönelik stratejiler geliştirerek ve yeni pazarlar arayarak sahada aktif olarak faaliyetlerini sürdürmeye başlamışlardır. Bankalar faaliyetlerini sürdürürken pazarın intiyaçlarını karşılamak durumundadırlar bunu yaparken de tasarruf sahiplerinin, iş adamlarının ve işletmelere yönelik faaliyetlerini şekillendirmelidirler. Bundan dolayı bankacılıkta pazarlama faaliyetleri tüketicilere yönelik bir çaba olup bankanın tüm süreçlerine yansımaktadır.

Bankacılık faaliyetleri dokunulamayan ve müşteriler ile ilişki düzeyi ise üyelik ilişkisine bağlı olarak süreklilik arz eden hizmetler içerisinde sınıflandırılmaktadır (Lovelock ve Wright, 2002). Hizmet sektörü içerisinde yer alan bankacılıkta pazarlama kavramı hizmet pazarlaması olarak değerlendirilmektedir. Hizmet pazarlama faaliyetlerinin amaçları arasında, işletmelerin karını maksimize ederken zararını da minimum seviyeye düşürmek ve pazar paylarını attırarak işletmenin hedeflerine ulaşmasını sağlamak vardır (içöz, 1999). Hizmet işletmelerinin pazarlama stratejileri onlara artı değer katan unsurlar sağlayacak şekilde belirlenmelidir. Bankalar açısından ele alındığında pazarlama hizmet satışı sağlamanın daha ötesinde müşterinin gözünde kişilik ve imaj oluşturulmasında da rol oynamaktadır (Öçer ve Kara, 2001). Bu bağlamda bankacıııktaki pazarlama faaliyetlerinin bankalara artı değer katması ve tüketicilere de artı değer sağlaması gerekir.

\subsection{Reklam ve TV Reklamları}

Reklam; bir bedel karşılığında, iletişim araçları vasıtasıyla geniş kitlelere bir ürün veya hizmetin duyurularak istenilen yönde tutum ve davranışların oluşturulmasını sağlayan eylemlerdir. Reklamlar sadece ürün ve hizmetin tanıtımında değil aynı zamanda işletmelerin kitlelere tanıtımında ve ikna edilmesinde, olumlu kurum imajının oluşturulmasında, satışların arttırılmasında, yeni pazarlara girilmesinde ve markaya bağ|ılığı güçlendirmede etkilidir (Aktuğlu, 2017: 159-160).

Tayfur (2010) televizyonu görsel-işitsel niteliği, çekicilik oranı ve algılanmasının rahat olmasından dolayı en etkin reklam aracı olarak tanımlamıştır. Özellikle televizyonlar günümüzde en etkili ve en sık kullanılan iletişim araçlarının başında gelmektedir. Reklamlar için ilk defa 1940'larda kullanılmaya başlanan televizyon aynı anda milyonlarca insanı kendine çekebilen içerikleriyle ve insanlara ses ve görüntüyü eş anlı olarak sunabilme özelliğiyle reklamcılar için uygun bir mecra olarak kabul edilmiştir. 1950'lerin ortalarına gelindiğinde bir reklam aracı olarak televizyon radyoyu geride bırakmış ve canlı yayınlanan spot reklamlarının yerini reklam filmleri almıştır ve zamanla televizyon fiziki özelliği ve içerik açısından reklamlar için güçlü ve vazgeçilmez bir araç olmuştur (Elden, 2009: 225).

Reklam çalışmalarında tek sesliliği oluşturacak mesajlar; amaca, mesaja ve hedef kitlenin özelliğine uygun kanallar aracılığıyla en doğru zamanda iletilir. Mesajların ve kullanılan mecraların işbirliği içinde ve tutarlı olması yapılan iletişim çalışmalarının daha etkin ve verimli olmasını sağlar (Tosun, 2017: 507).

Reklamın önemli unsurlarından biri olan sloganlar tüketicilerle iletişim kurulmasında ve reklamın ağızdan ağıza yayılmasında rol oynamaktadır. Amacı tüketicinin satın alma davranışını tanıttığı ürüne yöneltmek olan reklamlar bunu sağlamak için tanıtım filmlerinde tekrar edilebilecek ve akılda kalacak söylenişi kolay bir slogan veya söz grubundan faydalanmaktadırlar. Bu durumda nihai amaç hedef tüketicide uzun süre kalıcılık sağlamaktır (Nacak, 2012: 29). Bundan dolayı banka reklamlarında söylenen ve tekrar edilen kelimelerin analizi önemli bir araştırma konusunu oluşturmaktadır.

\subsection{Bankacilıkta Reklam}

Bankacılık sektöründe rekabetin artması, tüketicilerin birden fazla alternatifle karşı karşıya kalması ve daha bilinçli hale gelmesi neticesinde tercihlerinde ve davranışlarında değişimler olması, küreselleşme, teknoloji ve iletişim araçlarının gelişimiyle birlikte oluşan yeni uygulamaların etkisiyle denetleme ve düzenleme kurumlarının bankalar ve bankacılık işlemleri üzerinde sınırlamalar getirmesi bankaların ciddi baskılar altında olmasına neden olmuştur (Çolak, 2003: 22-23). Tüm bu gelişmelerin etkisinden dolayı 
bankaların pazarda rekabet edebilmeleri, pazar paylarını arttırabilmeleri veya var olan paylarını koruyabilmeleri için pazarlama odaklı yaklaşımlara başvurarak tüketici odaklı hareket etmeleri ve ürün ve hizmetlerini farklılaştırarak geniş bir tüketici segmentine hitap etmeleri gerekliliği kaçınılmaz olmuştur (Akhan, 2000: 14).

Bankacılıkta reklamların kullanılması özellikle bireysel bankacılık alanındaki müşterilere yönelik olup bankaların bu noktadaki amaçları olan müşteri sayısının arttırılması ürün çeşitliliğinin yanında hizmet kalitesiyle de doğrudan ilişkilidir. Bu noktada bankalar pazarda farklılaşmak için reklamlara başvurmaktadırlar (Doğru, Avşarlıgil ve Kıtlık 2013: 50).

İslami bankacılık sadece Müslümanlar değil aynı zamanda Müslüman olmayanlar arasında da yüksek taleplere sahiptir. İslami bankacılık ürünlerinin, uygun bir şekilde müşteri ihtiyaçlarını karşılayan farklı biçimleri vardır. Bankacılık sektörünün çalkantılı doğası ve katılımcıları arasındaki şiddetli rekabeti vardır. Rekabetin yoğunluğu, İslami bankaların “Müslüman toplumun dini yükümlülüklerini” yerine getirmekle sınırlı kalmamasını bunun yanında genel toplumun intiyaçlarını karşılama konusunda da yenilikçi yolları keşfetmelerini gerektiriyor. İslami bankacılık ürünlerinin varlığı ve bulunabilirliği hakkında insanların bilgilendirilmesi için yoğun reklamlara ihtiyacı vardır (Hakim, Bhatti ve Al-Jubari, 2011: 65).

Farkındalığın boyutlarından biri olan reklamlardan kitle iletişim reklamcılığı müşteriler için banka seçim kriteri olarak daha az önemlidir (Tara, Irshad, Khan, Yamin ve Rizwan, 2014: 356). Ancak getirilerinin belirsizliğine rağmen ticari bankalar daha fazla rekabet avantajı sağlamak için reklama büyük miktarlarda fon yatırmaya isteklidirler (Haron vd., 1994). Özellikle bankaların yaptıkları reklam çalışmaları son dönemlerde televizyonlarda yoğun olarak karşımıza çıkmaktadır. Katııım bankalarının farklılaşan ürün veya hizmetlerinin müşterilerce daha kolay ve hızlıca öğrenebilmesi için daha bilgilendirici ve bilinçlendirici özelliğe sahip reklam ve pazarlama faaliyetleri seçilmelidir (Metawa ve Almossawi, 1998: 303-304). İslami bankacılığın farkındalık eksikliğinin üstesinden gelmek için güçlü bir reklam kampanyasına ihtiyaç olduğu vurgulanmıştır (Gerrard ve Cunningham, 1997; Marimuthu, 2010). Ancak, tüm iş uygulamalarında olduğu gibi, reklamcılıkta da şeriat dikkatle izlenmelidir. Reklamverenler, ürün ve hizmetlerini abartmadan gerçekten açıklayan ve müşteriler arasında bu tür ürünlerle ilgili kafa karışıklığını azaltan en uygun mesajları iletmelidir. Bu ürünlerin varlığı ve ulaşılabilirliği hakkında insanların bilgilendirilmesi için yoğun reklama ihtiyaç vardır. Ancak tüm iş uygulamalarında olduğu gibi reklamcılıkta da islam hukuku dikkatle izlenmelidir. Reklamverenler de ürün ve hizmetlerini abartmadan gerçekten açıklayan ve müşteriler arasında bu tür ürünlerle ilgili kafa karışıklığını azaltan en uygun mesajları iletmelidir (Hakim vd., 2011: 65).

İslami bankacılık ürünlerinin İslami öğretilere göre reklamı yapılmalı ve çalışanlar da sattığı hizmetlerde bir kusur olduğunda bunu biliyorlarsa if̧̧a etmek durumundadırlar. Müslüman ülkelerde veya diğer ülkelerin sosyal normlarını etkileyen batı ülkelerinde reklam kampanyaları toplumun serbest değerlerini yansıtmaktadır. Bu durumda reklam kampanyalarını yürütenler de katılım bankalarının reklam kampanyalarının sosyal ya da yasal normları aşmayacağını taahhüt etmelidir (Haque, Ahmed ve Jahan, 2010). Bu bağlamda reklam kampanyalarını yürütenler bankaların çalışma prensibini ve değerlerini iyi bilerek reklam içeriklerini bu doğrultuda belirlemelidirler.

İslami bankacılık ürün ve hizmetleri hakkında yetersiz bilgi İslami bankacılığın payının düşük olmasını belirleyen faktörler arasında ikinci sırada yer almaktadır (Bashir vd., 2011). Wahyuni (2012) çalışmasında, İslami bankacılığı kullanma bilgisi ile kullanma niyeti arasındaki ilişkiyi incelemiştir ve aralarında pozitif yönde anlamlı bir ilişki bulmuştur. Bunun yanında daha iyi bilgiye sahip olan Müslüman toplumların İslami bankacılığı daha fazla kullanma niyetine sahip olduğunu belirtmiştir. Khan (2012) tarafından yapılan çalışmanın sonucunda da yoğun bilgilendirme ile Pakistan'daki insanların İslami bankacılığa karşı olumlu tutum ve yeterli farkındalığa sahip olduğunu ve geleneksel bankacılığın İslami bankacılığa geçtiğini kanıtlamıştır. Marimuthu (2010) yaptığı çalışmasında, katılımcıların \%57,6'sının temel İslami bankacılık kavramlarını bilmediğini tespit etmiştir. Hamid ve Nordin (2001), Malezya bankacılık tüketicileri üzerine yaptıkları çalışmalarında İslami ve geleneksel bankalar arasındaki farkın anlaşılması için yüksek düzeyde íslami bankacılık bilincinin gerekli olduğunu ve daha iyi tüketici eğitiminin, insanların İslami bankacılık ürünleri hakkında daha fazla 
bilinçlenmesinde etkili olacağını ortaya koymuşlardır. Bu bağlamda yapılan reklam içeriklerinin bankaya ilişkin bilgilendirici unsurlar içermesi önem arz etmektedir.

\section{Yöntem ve Analiz}

\subsection{Araştırma Yöntemi}

Bu çalışmada araştırmanın doğasına uygun olan nitel araştırma yöntemi tercih edilmiştir. Çalışma "ne" sorusuna cevap aramasından ve belirli bir zaman dilimini kapsamasından dolayı keşfedici ve kesitsel bir araştırmadır. Araştırma Yöntemi çerçevesinde araştırma kapsamında reklamlar içerik analizi tekniği ile çözümlenmiştir. İçerik analizi, araştırmacının herhangi bir kişi ya da duruma doğrudan dahil olmadan insan davranışlarını inceleme şansı bulduğu bir yöntemdir. İçerik analizinin tercih edildiği çalışmalarda İnsanın ürettiği her ürün potansiyel bir materyaldir. Bunun için içerik analizi basılı materyaller (gazete, günlük, kitap vb.) ya da film, şarkı, şiir vb. gibi ürünler üzerinde yapılabilmektedir (Fraenkel ve Wallen, 1996). İçerik analizi, basılı ya da görsel materyallerin sistematik bir şekilde taranarak belli kategoriler bakımından tematik olarak analiz edilmesini kapsadığı (Saban, 2009) ve özellikle medyada yer alan iletilerin yapısının ve içeriğinin değerlendirilmesini (Rubin, Rubin ve Piele, 2005) sağladığı için araştırmanın bu analiz yöntemiyle yapııması uygun görülmüştür.

Nitel araştırma yönteminin geleneği içinde ortaya çıkan amaçlı örnekleme yöntemi içerisinde yer alan ve olasılıklı olmayan amaçlı örnekleme türlerinden biri olan "ölçüt örnekleme" araştırma örnekleminin seçilmesinde kullanılmıştır. Ölçüt örneklemede araştırma örnekleminin oluşturulmasında belirli özelliklere sahip kişi, olay, nesne ya da durumlar seçilir. Örneklem için belirlenen ölçütü karşılayan birimler örnekleme alınır (Büyüköztürk, Çakmak, Akgün, Karadeniz ve Demirel, 2016: 92).

Araştırmaya konu örneklemin seçilmesinde bankaların katılım bankası olarak kurulmuş olması ve sadece katılım bankacılığı faaliyetlerini sürdürüyor olması kıstası belirlenmiş ve bu doğrultuda da Türkiyede katılım bankası olarak kurulmuş olan iki banka olduğu tespit edilmiştir. Araştırmanın örneklemini oluşturan ve ilk katılım bankalarından olan Albaraka Türk ve Kuveyt Türk, 83/7506 sayılı kanun hükmünde kararname ile özel finans kurumlarına yasal faaliyet izni verilmesi ile birlikte kurulmuş olup, Albaraka Türk 1985 yılında, Kuveyt Türk ise 1989 yılında faaliyetlerine başlamıştır (http://www.tkbb.org.tr/tarihce).

Bu doğrultuda örneklem olarak belirlenen iki katılım bankasının reklamlarından TV'de yayınlanmış olanlar analiz edilmiştir. TV reklamlarına ulaşmak için Youtube taranmıştır ve reklam dönemlerinin aynı olmasına özen gösterilerek reklamlar her iki bankanın youtube kanalından indirilmiştir. Youtube üzerinden erişilen reklamların 2014 yılı ve sonrası için sürekliliği arz ettiği ve her iki bankanın TV reklamcılığına bu dönemden sonra yoğunlaştığı tespit edilmiştir. Bu amaçla 2014-2018 (2018 yılının ilk yarısı) yılları arasında yayınlanan reklamların analizi yapıımıştır.

\subsection{Verilerin Analizi ve Kodlama}

Iç̧erik çözümlemesi ile yapılan bu araştırmada; toplamda 52 reklam incelenmiş olup, bunlardan 25 tanesi Albaraka Türk, 27 tanesi ise Kuveyt Türk reklamlarıdır.

Reklamların analizinde MAXQDA 18.0 paket programından yararlanılmıştır. Çalışmanın araştırma soruları gereği analizler yapılırken reklamlardaki renk, figür, amblem ve logolar dikkate alınmamış sadece söylem ve sloganlar incelenmiştir. İncelenen reklam filmleri baştan sona ikişer kez dinlenip bu doğrultuda kodlamalar yapılmıştır.

Yapılan kodlamalar üç farklı araştırmacı tarafından yeniden gözden geçirilip tasnif edilmiş ve daha sonra tümevarım yöntemi ile kodlama tablosu oluşturulmuştur. Yapılan kodalama ile reklamlarda hangi söylemlere yer verildiğinin ve bu söylemlerin hangi sıklıkla tekrar edilip öne çıkarıldığının analizi yapılmıştır.

İçerik çözümlemesi yapılırken Neuman (2006)'ın önerdiği süreçler takip edilmiş olup ilk adımla tüm reklamlar ikişer kez dinlenmiştir. Ardından kodlamanın ilk basamağını oluşturan açık kodlama yapılmıştır. 
Tablo 1'de son aşamada örgüte ve çalışma prensibine ilişkin kategori altında toplanan çalışmanın ilk basamağını oluşturan açık kodlama örneği verilmiştir.

Tablo 1. Örnek Açık Kodlama Tablosu

\begin{tabular}{|c|c|}
\hline \multicolumn{2}{|c|}{ Örgüte ve Çalışma Prensibine ilişkin Unsurlar } \\
\hline Sağlam & Yanınızda olan \\
Sağlamcı & Net bilgi veren \\
Hızlı ve emin & Şeffaf \\
Hesabını bilen & Değerin ışı̆ıında \\
Fırsatları değerlendiren & Hayalleri gerçeğe dönüştüren \\
Geleceğini sağlama alan & Geleceği net gören \\
Değerlere önem veren & Mutluluğunuza katkı sağlayan \\
Değerler ışı̆̆ında çalışan & Hayatı kolaylaştıran \\
Değerli & Net çözümler, net sonuçlar \\
Değer bilen & Kötü sürpriz yok \\
Değerlerinden taviz vermeyen & Belirsizlik yok \\
Değerleri için çalışan & Tanıyıp anlayan \\
Değerleri yaşatan & Tasarrufçu \\
Değerlerinizin bankası & İsraftan kaçınan \\
ìtiyaç anında yanınızda & Iş̧in ölçüsünü bilen \\
Her anınızda mutluluğunuz için & Emeği ve alınterini gören \\
çalışır & Güvende hissettiren \\
Bizden biri & Hassasiyetlere önem veren \\
Yarınları düşünen & Takım olmanın gücüne inanan \\
Yükünü hafifleten & \\
Hassasiyetli & \\
\hline
\end{tabular}

Açık kodlama süreci sonucunda toplamda 90 kod ortaya çıkmış ve bu kodların tamamının kodlanma sayısının 283 olduğu tespit edilmiştir. Bu kodlamanın 156 tanesi Albaraka Türk reklamlarından, 127 tanesi ise Kuveyt Türk reklamlarından elde edilmiştir.

Tablo 2. Örnek Seçici Kodlama Tablosu

\begin{tabular}{|c|}
\hline Toplumsal Değerlere Yakınlık \\
\hline Değerlere önem veren \\
\hline Değerler ışığında çalışan \\
\hline Değerli \\
\hline Değer bilen \\
\hline Değerlerinden taviz vermeyen \\
\hline Değerleri için çalışan \\
\hline Değerleri yaşatan \\
\hline Değerlerinizin bankası \\
\hline Değerin ışı̆ında \\
\hline Yanınızda olan \\
\hline
\end{tabular}


Çalışmada, analizin ikinci aşamasında açık kodlamanın yapılmasının ardından açık kodlamada ortaya çıkarılan kodların birbirleriyle ilişkilendirilmesi, birbirlerine yakın olan kodların birleştirilmesi ve yeniden oluşturulması ile birlikte temalar oluşturulmuştur. Temalar işletme bölümünden üç, psikoloji bölümünden bir öğretim elemanın ortak çalışması sonucunda belirlenmiştir.

Seçici kodlama olarak adlandırılan son aşamada ise ilk iki aşama neticesinde oluşturulan temalar çerçevesinde reklamlar tekrar gözden geçirilerek temaların bütünleştirilmesi sağlanmış ve ortaya kategoriler konulmuştur. Açık kodlama ile başlayıp seçici kodlama ile son bulan verilerin kodlanması sürecinde elde edilen kod, tema ve kategori sayıları aşağıda yer alan Tablo 3'te verilmiştir.

Tablo 3. Analiz Sonucu Oluşturulan Kod, Tema ve Kategori Sayıları

\begin{tabular}{|l|c|}
\hline & Toplam \\
\hline Kod & 90 \\
\hline Oluşan Tema & 62 \\
\hline Kategori & 6 \\
\hline
\end{tabular}

Analizin son aşaması olan seçici kodlama sonucunda oluşturulan 6 kategori ve onları oluşturan temalar Tablo 4'de verilmiştir.

Tablo 4. Oluşan Kategori ve Temalar

\begin{tabular}{|l|l|}
\hline Örgüte ve Çalışma Prensibine ilişkin Unsurlar & Sosyal ilişki ve iç Motivasyon Unsurları \\
\hline Sağlam değerlerle çalışan & Samimiyet \\
\hline Hızlı ve emin & Dostluk \\
\hline Hesabını bilen & Gülümsemek \\
\hline Fırsatları değerlendiren & Mütevazı \\
\hline Toplumsal değerlere yakınlık & Huzur \\
\hline ihtiyaç anında yanında & Sabır \\
\hline Her anınızda mutluluğunuz için çalışır & Güven \\
\hline Bizden biri & Heyecan \\
\hline Yükünü hafifletip hayatı kolaylaştııır & Umut \\
\hline Hassasiyetlere önem veren & Kültürel Değer Unsurları \\
\hline Şeffaf & Paylaşımcı \\
\hline Hayalleri gerçeğe dönüştüren & Komşuluk \\
\hline Geleceği net gören & Hoşgörü \\
\hline Mutluluğunuza katkı sağlayan & Dini Unsurlar \\
\hline Net çözümler, net sonuçlar & Alınteri \\
\hline Tanıyıp anlayan & Bereket \\
\hline Tasarrufçu & Niyet \\
\hline Emeği ve alın terini gören & Hayır \\
\hline Güvende hissettiren & Dua \\
\hline Takım olmanın gücüne inanan & Helal \\
\hline Ekonomik ve Finansal Unsurlar & Temiz kazanç \\
\hline Puan kazandıran & Kâbe \\
\hline
\end{tabular}


Tablo 4. Oluşan Kategori ve Temalar (Devamı)

\begin{tabular}{|l|l|}
\hline Ekonomik ve Finansal Unsurlar & Dini Unsurlar \\
\hline Bütçeni korur & Kutsal Topraklar \\
\hline Üretime katılan & Şükür \\
\hline Sizin ve ülke için çalışan ve kazandıran & Hac/Umre \\
\hline Karlı ve Kazançıı & Kubbe \\
\hline Hakkaniyetli kazanç & Inanç \\
\hline Pratik çözümler bulan & Evrensel Değer Unsurları \\
\hline Yüksek kar payı paylaşımı & Yardımcı \\
\hline Faizsiz sistem ve kazanç & Sevgi \\
\hline Birikimleri değerlendiren & Iyilik \\
\hline Ekstra ücret almayan ve kesinti yapmayan & Insanlık \\
\hline & Eşit davranan/ Adil \\
\hline & Merhamet \\
\hline
\end{tabular}

\section{Bulgular ve Yorum}

Açık kodlama sonucunda ortaya çıkan kodlardan en fazla tekrar eden kelimeler tespit edilmiştir. Tablo 5 'te bu kelimeler ve tekrar sayıları yer almaktadır.

Tablo 5. En Fazla Tekrarlanan Kodlar ve Sayıları

\begin{tabular}{|l|c|}
\hline Kod & Tekrarlanma \\
\hline Sağlam & 28 \\
\hline Karlı & 16 \\
\hline Bereket & 14 \\
\hline Birikim & 12 \\
\hline Değer katar & 11 \\
\hline
\end{tabular}

En fazla tekrarlanan kelimenin "sağlam" olmasının nedeni Kuveyt Türk bankasının reklam sloganının "sağlam bankacılık" olmasından kaynaklanmaktadır. Kuveyt Türk reklamlarının genel sloganı "sağlam bankacııık" iken, Albaraka Türk "değerlerinizin bankası" sloganı ile reklamlarını yayınlamıştır. Tüketicilerin bankacııık sistemine giriş sebeplerinin temelini ellerindeki tassarruflarını değerlendirip kar elde etmek oluşturmaktadır. En fazla tekrarlanan ikinci kelimenin "karı" olması ise katıım bankalarının tüketicilerinin asıl amaçlarına İslami prensipler çerçevesinde ulaşmalarını sağlayacaklarını vaat etmeleri ve bunu da reklamlarında sıklıkla dile getirmeleridir. Bir diğer kod olan "bereket" ise karlı ile aynı vaadi ifade etmekte ancak katılım bankalarının doğası gereği bereket kelimesinin kullanıldığı düşünülmektedir.

Reklamların ürünleri ve hizmetleri tanıtmalarının yanında tüketiciyi bilgilendirme özellikleri de bulunmaktadır. Yapılan analiz neticesinde katılım bankaları reklamlarında ürünleri ve işletmeyi tanıtan unsurların yer aldğı tespit edilmiş ve bu unsurlar "örgüte ve çalışma prensiplerine ilişkin unsurlar" başlığı altında kategorileştirilmiştir. 
Tablo 6. Örgüte ve Çalışma Prensibine İlişkin Unsurlar

\begin{tabular}{|l|c|}
\hline Örgüte ve Çalışma Prensibine İlişkin Unsurlar & Açık Kodlama Sayıları \\
\hline Sağlam değerlerle çalışan & 37 \\
\hline Toplumsal değerlere yakınlık & 27 \\
\hline Tasarrufçu & 8 \\
\hline İtiyaç anında yanında & 7 \\
\hline Hayalleri gerçeğe dönüştüren & 7 \\
\hline Hassasiyetlere önem veren & 5 \\
\hline Emeği ve alın terini gören & 4 \\
\hline Net çözümler, net sonuçlar & 4 \\
\hline Tanıyıp anlayan & 3 \\
\hline Yükünü hafifletip hayatı kolaylaştırır & 2 \\
\hline Hızlı ve emin & 2 \\
\hline Şeffaf & 2 \\
\hline Güvende hissettiren & 2 \\
\hline Fırsatları değerlendiren & 1 \\
\hline Her anınızda mutluluğunuz için çalışır & 1 \\
\hline Bizden biri & 1 \\
\hline Geleceği net gören & 1 \\
\hline Mutluluğunuza katkı sağlayan & 1 \\
\hline Takım olmanın gücüne inanan & 2 \\
\hline Toplam & 2 \\
\hline
\end{tabular}

Yapılan analizlerde bankacılık sisteminin özelliği gereği reklamlarda ekonomik ve finansal öğelerin vurgulandığı tespit edilmiştir. Tespit edilen bu kelimeler "ekonomik ve finansal unsurlar" başlığı altında kategorileştirilmiştir. Bu unsurlar ve bunların ilk aşamada yapılan açık kodlanma sayıları Tablo 7'de yer almaktadır.

Tablo 7. Ekonomik ve Finansal Unsurlar Faktörünü oluşturan Temalar

\begin{tabular}{|l|c|}
\hline Ekonomik ve Finansal Unsurlar & Açık Kodlama Sayıları \\
\hline Karlı ve Kazançlı & 16 \\
\hline Birikimleri değerlendiren & 8 \\
\hline Faizsiz sistem ve kazanç & 7 \\
\hline Hakkaniyetli kazanç & 5 \\
\hline Ekstra ücret almayan ve kesinti & 5 \\
\hline Sizin ve ülke için çalışan ve kazandıran & 4 \\
\hline Yüksek kar payı paylaşımı & 3 \\
\hline Üretime katılan & 2 \\
\hline Pratik çözümler bulan & 2 \\
\hline Puan kazandıran & 1 \\
\hline Bütçeni korur & 1 \\
\hline Toplam & $\mathbf{5 4}$ \\
\hline
\end{tabular}


Tablo 7 incelendiğinde en fazla kodlama sayısına sahip temanın "karlı ve kazançlı" olduğu görülmektedir. Bu doğrultuda bankaların esas işleyiş amaçlarından biri olan kar ve kazanç sağlama unsurunun katılım bankaları reklamlarında da önemli bir mesaj olduğu görülmektedir.

Katılım bankaları reklamlarının ortak özelliklerinden biri de diğer bankalardan farklı olarak özellikle dini söylemlere yer vermelidir. Yapılan analiz neticesinde bu söylemler "dini unsurlar faktörü" altında kategorileştirilmiştir.

Tablo 8. Dini Unsurlar Faktörünü Oluşturan Temalar

\begin{tabular}{|l|c|}
\hline Dini Unsurlar & Açık kodlama Sayıları \\
\hline Bereket & 14 \\
\hline Hac/Umre & 8 \\
\hline Alınteri & 6 \\
\hline Niyet & 4 \\
\hline Helal & 4 \\
\hline Temiz kazanç & 4 \\
\hline Dua & 3 \\
\hline Kutsal Topraklar & 2 \\
\hline Hayır & 2 \\
\hline Kâbe & 1 \\
\hline Şükür & 1 \\
\hline Kubbe & 1 \\
\hline İnanç & 1 \\
\hline Toplam & $\mathbf{5 1}$ \\
\hline
\end{tabular}

Katılım bankalarının bir diğer özelliğide dini bayram temalı reklamlar yapmalarıdır. Her iki bankanın incelenen reklamları arasında neredeyse her yıla özgü çekilen ramazan ayı temalı reklamlar yer almıştır. Özellikle Kuveyt Türk ramazan temalı reklamları daha fazla yapmış ve bu reklamlarda dini söylemlere yer vermiştir. Yine dinin gereklerinden olan hac ve umre vazifesine yönelik reklamların Albaraka Türk tarafından yapıldığı belirlenmiştir.

Analizi yapılan reklamlarda dini unsurların yanında toplumsal ilişkileri sağlayan öğelerin de vurgusu yapılmıştır. Bu söylemler "sosyal ilişki ve iç motivasyon unsurları" altında kategorileştirilmiş olup bunların ilk aşamada yapılan açık kodlanma sayıları Tablo 9'da yer almaktadır.

Tablo 9. Sosyal iliş̧ki ve İç Motivasyon Unsurları Faktörünü Oluşturan Temalar

\begin{tabular}{|l|c|}
\hline Sosyal ilişki ve iç Motivasyon Unsurları & Açık Kodlama Sayıları \\
\hline Dostluk & 5 \\
\hline Gülümsemek & 5 \\
\hline Huzur & 3 \\
\hline Samimiyet & 2 \\
\hline Heyecan & 2 \\
\hline Sabır & 2 \\
\hline Güven & 2 \\
\hline Mütevazı & 1 \\
\hline Umut & 1 \\
\hline Toplam & 23 \\
\hline
\end{tabular}


Tablo 9 incelendiğinde en fazla kodlanma sayısına sahip iki unsurun "dostluk" ve "gülümseme" olduğu görülmektedir. Bu iki unsurun özellikle vurgulanması pozitif duygu durumlarını yansıtmak amaçlı olduğu söylenebilir. Tabloda yer alan unsurların hedef kitle ile duygusal bağ kurma amaçlı olarak reklamlarda kullanıldığı düşünülmektedir.

Tablo 10'da reklamlarda vurgulanan kelimelerin "evrensel değer unsurları" kategorisinde toplandığı görülmektedir. Bu unsurların reklamlarda kullanılarak tüm insanlığı kucaklama mesajı verildiği düşünülmektedir.

Tablo 10. Evrensel Değer Unsurları Faktörünü Oluşturan Temalar

\begin{tabular}{|l|c|}
\hline Evrensel Değer Unsurları & Açık Kodlanma Sayıları \\
\hline Sevgi & 3 \\
\hline İyilik & 3 \\
\hline Yardımcı & 2 \\
\hline İnsanlık & 1 \\
\hline Eşit davranan/ Adil & 1 \\
\hline Merhamet & 1 \\
\hline Toplam & $\mathbf{1 1}$ \\
\hline
\end{tabular}

Reklamlar hitap ettikleri hedef kitlenin kültürel değerlerine uygun mesajları vermelidirler. Yapılan analizde katılım bankaları reklamlarında içinde bulunduğumuz kültürün değerlerine ilişkin söylemlerin vurgulandığı tespit edilmiş ve bunlar "kültürel değer unsurları" başlığı altında kategorileştirilmiştir.

Tablo 11. Kültürel Değer Unsurları Faktörünü Oluşturan Temalar

\begin{tabular}{|l|c|}
\hline Kültürel Değer Unsurları & Açık Kodlanma sayıları \\
\hline Paylaşımcı & 4 \\
\hline Komşuluk & 1 \\
\hline Hoşgörü & 1 \\
\hline Toplam & 6 \\
\hline
\end{tabular}

Tablo incelendiğinde oluşan üç temadan en fazla kodlanma sayısına sahip unsurun paylaşımcı olduğu görülmektedir. Vurgulanan "komşuluk" unsurunun Türk kültürüne özgü olduğu dikkat çekmektedir.

Yapılan analiz neticesinde oluşan 9 kategori ve bunları oluşturan kod ve tema sayıları Tablo 12' de yer almaktadır.

Tablo 12. Kategorileri Oluşturan Tema Ve Kod Sayıları

\begin{tabular}{|l|c|c|}
\hline Oluşan Kategoriler & Oluşan Tema Sayısı & Oluşan Kod Sayısı \\
\hline Örgüte ve Çalışma Prensibine İlişkin Unsurlar & 20 & 39 \\
\hline Dini Unsurlar & 13 & 13 \\
\hline Ekonomik ve Finansal Unsurlar & 11 & 19 \\
\hline Sosyal İlişki ve İç Motivasyon Unsurları & 9 & 9 \\
\hline Evrensel Değer Unsurları & 6 & 7 \\
\hline Kültürel Değer Unsurları & 3 & 3 \\
\hline Toplam & 62 & 90 \\
\hline
\end{tabular}


Tablo 12 incelendiğinde, "örgüte ve çalışma prensibine ilişkin unsurları" ilk aşamada yapılan açık kodlama ile ortaya çıkan 39 kodun ilişkilendirilmesi 20 tema kategorileştirilmesi sonucunda oluşturulduğu görülmektedir. İlk aşamada ortaya çıkan 19 kodun ilişkilendirilmesi neticesinde belirlenen 11 tema ise "ekonomik ve finansal unsurlar" başlığı altında kategorileştirilmiştir. Sosyal ilişki ve iç motivasyon unsurları, kültürel değer unsurları ve dini unsurların oluşturulmasını sağlayan her kategorinin kod ve tema sayılarının ise eşit olduğu görülmektedir.

\section{Sonuç}

İşleyiş ve çalışma prensiblerinin geleneksel bankacılık sisteminden farklılaştığı katılım bankaları reklamlarının analiz edildiği bu çalışma neticesinde katılım bankaları reklamlarında vurgulanan ögeler açığa çıkarılmıştır. Çalışma sonucunda reklam mesajlarının içerikleri; (1) örgüte ve çalışma prensibine ilişkin unsurlar, (2) ekonomik ve finansal unsurlar, (3) sosyal ilişki ve iç motivasyon unsurları, (4) kültürel değer unsurları, (5) dini unsurlar ve (6) evrensel değer unsurları şeklinde sınıflandırılmıştır. Varoluş nedeni ve çalışma sisteminin reklamlarda anlatılıyor olmasının yanında banka reklamları doğası gereği hizmet ve ürünlerin tanıtımını da içermektedir.

Katılım bankalarının ilk çıkış reklamları çalışma prensiplerini vurgulayan tanıtııı reklamlar olup bu reklamlarda örgüte ve çalışma prensiblerine ilişkin bilgilendirme mesajlarının olduğu tespit edilmişir. Bunun nedeni olarak katııım bankalarının işleyiş yapısını farklı tüketici gruplarına anlatma gerekliliği görülmektedir. Albaraka Türk'ün ilk kuruluş döneminde "neden Albaraka" sorusu teması üzerinden reklamlar yapılmış olup bu reklamlarda daha çok sistemin ve sağladığı kazancın faizsizliği ve sistemin güvenilirliği vurgulanmıştır. Tara vd. (2014), Pakistan'da İslami bankacılığa yönelik yaptıkları çalışmalarında İslami bankacılığa ilişkin bilgilendirme yapılmasının farkındalığa etki ettiğini ortaya koymuşlardır. Bunun yanında karlılık ve düşük işlem maliyetinin de (Hasan vd., 2012) İslami bankaların tercih edilmesinde etkili olduğu ortaya konulmuştur. Katılım bankacılığı reklamlarının analizi sonucunda ortaya çıkan ekonomik finansal unsurlar ve örgüte ve çalışma prensibine ilişkin unsurların bu çalışmalarla örtüştüğü görülmektedir. Bu bağlamda reklamlarda bankayı tanıtıcı ve işleyişi anlatııı mesajların verilmesi önem arz etmektedir

Bunun yanında katılım bankaları islami prensipler çerçevesinde çalıştığını vurgulamak amacıyla reklamlarında dini unsurlara yer vermiştir. Böylelikle hem dini hassasiyetleri olan tüketici kitlesine hitap etmiş hem de çalışma sisteminin dayandığı temelleri vurgulamışladır. Örneğin; Kuveyt Türk gerçek temalı iki reklam filmi ile sağladığı kazancın ve bankacılık sisteminin gerçek ve doğru olduğu vurgusunu yapmıştır.

Haque vd. (2010) ve Hakim vd. (2011) katılım bankacılığına yönelik yaptıkları çalışmalarında reklam ve tanıtımlarda kullanılan dini kelimeler ve Kur'an kelimelerinin Müslümanlarda etkili olduğunu ortaya koymuşlardır. Çalışma sonucunda oluşan dini unsurların da reklamlarda vurgulanıyor olması önceki çalışmaları destekler niteliktedir.

İslami bankacığın tercih edilmesinde etkili olan faktörlerin başında dini motivasyonun yer alması (Metawa ve Almossawi, 1998; Othman ve Owen, 2001; Okumuş, 2005; Al-Ajmi vd., 2009; Gait ve Worthington, 2009; Gait, 2009; Abduh ve Omar, 2012; Imtiaz, Murtaza, Abaas ve Hayat, 2013; Okumuş ve Genç, 2013; Ser, Nursyafira ve Sundram, 2014) Reklamların analizi sonucunda ortaya çıkan dini unsular kategorisi ile örtüşmektedir.

İslami bankaların tercih edilmesinde etkili olan bir diğer unsurun ürün ve hizmet kalitesi ve çalışanların yaklaşımlarının olduğu yapılan çalışmalarla (Erol ve El-Bdour, 1989; Dusuki ve Abdullah, 2007; Haque vd., 2009; Awan ve Bukhari, 2011; Özsoy vd., 2013; Ramadan, 2013; Kader vd., 2014) ortaya konmuştur.

Değişen ve dönüşen teknoloji ile günün gereklerinin farklılaşması reklamların içeriklerinde de etkili olmuştur. Son dönemde yapılan Albaraka Türk reklamları teknoloji, inovasyon ve dijital bankacılığa vurgu yapmaktadır. Ancak yine bu reklamlarda da verilen mesajlar yine aynı kalmakta tüketicilerin değerlerine vurgu yapılmaktadır. Reklamlarda kazançlı vurgusu kar ve bereket mesajları ile tüketicilere iletilmiştir. Reklamlarda hitap edilen tüketici kitlesine hem kültürel değerlere önem verildiği vurgulanarak sizden biri 
mesajı verilmeye çalışılmış hem de evrensel değerlere de saygılı olunduğu ve bu değerlere de önem verildiği mesajı iletilmiştir. Sonuç itibariyle bakıldığında her iki banka da temelde çalışma prensiplerini anlatmakla birlikte kazançlı olduklarının vurgusunu özellikle yapmışlardır. Analiz sonucundan da anlaşıldığı üzere bankalar çalışma prensiplerine ilişkin vurgunun yapıldığı reklamlarda bu prensipleri dini öğeler kullanarak anlatmışlar ve bunları aynı zamanda evrensel değerlerle de ilişkilendirmişlerdir.

Gelecek çalışmalarda bankaların reklam analizlerine yönelik olarak katılım ve geleneksel bankacılık reklamları karşılaştırmalı bir analizle ortaya konulabilir. Böylece bu çalışmadan elde edilen unsurların geleneksel bankacılık reklamlarındaki yeri de tespit edilmiş olacaktır. Bu çalışma sonucunda ortaya çıkan kodların gelecekte yapılacak katılım bankacılı̆ı̆ reklamlarının içeriğinin belirlenmesinde yol gösterici olacağı düşünülmektedir.

\section{Son Notlar}

1. Bu çalışma Business \& Organization Research Conference (2018, Safranbolu)'da bildiri olarak sunulmuştur.

\section{Kaynaklar}

Abduh, M., \& Omar, M. A. (2012). İslamic-bank selection criteria in Malaysia: An AHP approach. Business Intelligence Journal, 5(2), 271-281.

Akhan, H. (2000), Türk bankacılık sektörü yeniden yapılanırken beklentiler. Bankacılar Dergisi, 34, 13-16.

Aktuğlu, K. I. (2017). Marka yönetimi: Güçlü ve başarılı markalar için temel ilkeler (6. Baskı). İstanbul: iletişim Yayınları.

Al-Ajmi, J., Abo Hussain, H., \& Al-Saleh, N. (2009). Clients of conventional and islamic banks in Bahrain: How they choose which bank to patronize. International Journal of Social Economics, 36(11), 1086-1112.

Amin, M., \& Isa, Z. (2008). An examination of the relationship between service quality perception and customer satisfaction: A SEM approach towards Malaysian islamic banking. International Journal of islamic and Middle Eastern Finance and Management, 1(3), 191-209.

Amstrong, G., \& Kotler, P. (2009). Principle of marketing (11th ed.). New York: Pearson Prentice Hall.

Awan, H. M., \& Bukhari, K. S. (2011). Customer's criteria for selecting an islamic bank: Evidence from Pakistan. Journal of islamic Marketing, 2(1), 14-27.

Bashir, A., Sajid, M. R., \& Iqbal, S. (2011). Barriers to islamic banking growth-bank employees' perspective from Pakistan. Asian Journal of Finance \& Accounting, 3(1), 56-71.

Bilir, A., \& Özgen, H. (2010). Katılım bankalarında müşteri memnuniyetinin belirlenmesi üzerine Hatay ilinde bir araştırma. Journal of the Cukurova University Institute of Social Sciences, 19(3), 39-62.

Büyüköztürk, Ş., Çakmak, E. K., Akgün, Ö. E., Karadeniz, Ş., \& Demirel, F. (2016). Bilimsel araştırma yöntemleri (20. baskı). Pegem Akademi.

Çolak, Ö. F. (2003, Eylül) Piyasaya giriş engelleri ve rekabet: Bankacılık sektörü üzerine bir analiz. Rekabet Düzenlemeler ve Politikalar Kongresi, Muğla Üniversitesi, Muğla.

Darçın, A. (2007). Özel finans kurumlarının katılım bankaları'na dönüşümünün sebepleri ve sonuçları. Atılım Üniversitesi, Yayımlanmamış Yüksek Lisans Tezi, Ankara.

Doğru, E., Avşarlıgil, N., \& Kıtlık, Ö. H. (2013). Reklamlarda oynayan ünlülerın banka tercihleri üzerine etkisi. Organizasyon ve Yönetim Bilimleri Dergisi, 5(2), 51-62.

Dusuki, A. W., \& Abdullah, N. I. (2007). Why do Malaysian customers patronise İslamic banks? International Journal of Bank Marketing, 25(3), 142-160.

Echchabi, A., \& Aziz, H. A. (2012). Empirical investigation of customers' perception and adoption towards íslamic banking services in Morocco. Middle-East Journal of Scientific Research, 12(6), 849-858.

Elden, M. (2009). Reklam ve reklamcilı. İstanbul: Say Yayınları.

Erol, C., \& El-Bdour, R. (1989). Attitudes, behaviour, and patronage factors of bank customers towards islamic banks. International Journal of Bank Marketing, 7(6), 31-37.

Fraenkel, J. R., \& Wallen, N. E. (1996). How to design and evaluate research (3. baskı). New York: Mc Graww-Hill. 
Gait, A. H. (2009). The impact of demographic variables on Libyan retail consumers'attitudes towards İslamic methods of finance. Islamic Economic Studies, 17(1).

Gait, A. H., \& Worthington, A. C. (2007). An empirical survey of individual consumer, business firm and financial institution attitudes towards İslamic methods. Faculty of Commerce-Accounting \& Finance Working Papers.

Gerrard, P., \& Cunningham, J. B. (1997). İslamic banking: A study in Singapore. International Journal of Bank Marketing, 15(6), 204-216.

Grönroos, C. (1990). Service management and marketing: Managing the moments of truth in service competition. Jossey-Bass.

Hakim, S. A., Bhatti, O. K., \& Al-Jubari, I. (2011). Advertising of İslamic banking products. Annals of Management Research, 1(2), 60-70.

Hamid, A., \& Nordin, N. (2001). A study on İslamic banking education and strategy for the new millennium-Malaysian experience. International Journal of Islamic Financial Services, 2(4), 3-11.

Hamzah, N., Ishak, N. M., \& Nor, N. I. M. (2015). Customer satisfactions on İslamic banking system. Journal of Economics, Business and Management, 3(1), 140-144.

Haque, A., Osman, J., \& Ismail, A. Z. (2009). Factor influences selection of İslamic banking: A study on Malaysian customer preferences. American Journal of Applied Sciences, 6(5), 922-928.

Haque, A., Ahmed, K., \& Jahan, S. I. (2010). Shariah observation: Advertising practices of Bank Muamalat in Malaysia. Journal of islamic Marketing, 1(1), 70-77.

Haron, S., Ahmad, N., \& Planisek, S. L. (1994). Bank patronage factors of muslim and non-muslim customers. International Journal of Bank Marketing, 12(1), 32-40.

Hasan, S. A., Subhani, M. I., \& Osman, M. (2012). Consumer criteria for the selection of an İslamic Bank: Evidence from Pakistan. MPRA Paper No. 40384.

Imtiaz, N., Murtaza, A., Abaas, M. A., \& Hayat, K. (2013). Factors affecting the individual's behavior towards İslamic banking in Pakistan: An empirical study. Educational Research International, 1(2), 106-111.

İçöz, O. (1999). Hizmet pazarlamasında internet kullanımı. Dokuz Eylül Üniversitesi Sosyal Bilimler Enstitüsü Dergisi, 1(3), 27-37.

Kader, R. A., Zakaria, R. H., Razali, N., \& Abdullah, N. (2014). Why this bank? Understanding customers' preference for an İslamic bank in a competitive market. Journal of İslamic Economics, Banking and Finance, 113(3199), 1-16.

Karaca, G. (2006). Hizmet pazarlaması açısından mali müşavirlik hizmetlerinde pazarlama yönetim süreci ve bir uygulama. Marmara Üniversitesi Sosyal Bilimler Enstitüsü, Basılmamış Yüksek Lisans Tezi, İstanbul.

Karafakıoğlu, M.(2012). Pazarlama ilkeleri (5. baskı). İstanbul: Türkmen Kitabevi.

Kaytancı, B. G., Ergeç, E. H., \& Toprak, M. (2013). Katılım bankası müşterilerinde bankacılık ürün ve hizmetlerine yönelik memnuniyet: Türkiye örneği. International Conference on Eurasian Economies.

Khan, H. N., \& Asghar, N. (2012). Customer awareness and adoption of İslamic banking in Pakistan. Interdisciplinary Journal of Contemporary Research in Business, 3(9), 359-366.

Khattak, N. A., \& Ur Rehman, K. (2010). customer satisfaction and awareness of i̇slamic banking system in Pakistan. African Journal of Business Management, 4(5), 662-671.

Lovelock, C. H., \& Wright, L. (2002). Principles of service marketing and management (2nd ed.). New Jersey: Prentice Hall.

Marimuthu, M., Jing, C. W., Gie, L. P., Mun, L. P., \& Ping, T. Y. (2010). İslamic Banking: Selection criteria and implications. Global Journal of Human \& Social Science, 10(4), 52-62.

Metawa, S. A., \& Almossawi, M. (1998). Banking behavior of İslamic bank customers: Perspectives and implication. International Journal of Bank Marketing, 16(7), 299-313.

Nacak, O. (2012). Bilinçaltı reklam uygulamaları: Galatasaray Üniversitesi ögrencileri üzerine bir uygulama. Süleyman Demirel Üniversitesi, Yayımlanmamış Yüksek Lisans Tezi, Isparta.

Naser, K., Jamal, A., \& Al-Khatib, K. (1999). İslamic banking: A study of customer satisfaction and preferences in Jordan. International Journal of Bank Marketing, 17(3), 135-151.

Neuman, W. L. (2006) Social Research Methods: Qualitative and Quantitative Approaches (6th Ed.). Pearson International Edition, USA.

Okumuş, H. Ş. (2005). Interest-free banking in Turkey: A study of customer satisfaction and bank selection criteria. Journal of Economic Cooperation, 26(4), 51-86. 
Okumuş, H. Ş., \& Genç, E. G. (2013). Interest free banking in Turkey: A study of customer satisfaction and bank selection. European Scientific Journal, 9(16), 144-166.

Othman, A., \& Owen, L. (2001). The multi dimensionality of Carter Model to measure customer service quality (SQ) in İslamic banking industry: A study in Kuwait finance house. International Journal of Islamic Financial Services, 3(4), 1-12.

Öçer, A., \& Kara, G. (2001). Bankacılık sektöründe pazarlama faaliyetleri: Trabzon'da örnek uygulama. Pazarlama Dünyası, 1, 18-28.

Özkan, H.(2012). Katılım bankacılı̆ının klasik bankalarla karşılaştırılması ve muhasebe uygulamaları. Niğde Üniversitesi, Yayımlanmamış Yüksek Lisans Tezi, Niğde.

Özsoy, İ., Görmez, B., \& Mekik, S. (2013). Türkiye'de katılım bankalarının tercih edilme sebepleri: Ampirik bir tetkik. Yönetim ve Ekonomi: Celal Bayar Üniversitesi Iktisadi ve Idari Bilimler Fakültesi Dergisi, 20(1),187-206.

Ramadan, Z. S. (2013). Jordanian criteria for İslamic banks selection: Evidence from the Jordanian banking sector. International Journal of Academic Research in Accounting, Finance and Management Sciences, 3(3), $139-145$.

Rubin, R. B., Rubin A. M., \& Piele, L. J. (2005). Communication research: Strategies and sources (6th Ed.). California: Wadsworth Publications.

Saban, A. (2009). Öğretmen adaylarının öğrenci kavramına ilişkin sahip oldukları zihinsel imgeler. Türk Eğitim Bilimleri Dergisi, 7(2), 281-326.

Sarı, B. (2010). Türkiye'de faizsiz bankacılık sektöründe müşteri memnuniyeti ve banka tercihleri üzerine bir uygulama. İstanbul Ticaret Üniversitesi Sosyal Bilimler Enstitüsü, Yayınlanmamış Yüksek Lisans Tezi, İstanbul.

Ser, N., Nursyafira, F., \& Sundram, V. (2014). Determinants of attitude towards íslamic financing among halal-certified micro and SMEs. Available at SSRN 2540610.

Şendoğdu, A. A. (2014). Özel kamu ve katılım bankalarında müşteri memnuniyeti ve müşteri sadakatine yönelik bir araştırma. Suleyman Demirel University Journal of Faculty of Economics \& Administrative Sciences, 19(2), 91-106.

Tara, N., Irshad, M., Khan, M. R., Yamin, M., \& Rizwan, M. (2014). Factors influencing adoption of İslamic banking: A study from Pakistan. Journal of Public Administration and Governance, 4(3), 352-367.

Tayfur, G. (2010). Reklamcılık. İstanbul: Nobel Yayın.

Tosun, B. N. (2017). Marka yönetimi (3. baskı). İstanbul: Beta Basım Yayın.

Wahyuni, S. (2012). Moslem community behavior in the conduct of islamic bank: The moderation role of knowledge and pricing. Procedia-Social and Behavioral Sciences, 57, 290-298.

Yılmaz, H.N. (2010). Türkiye'de katılım bankaları alanında yaşanan gelişmeler ve katılım bankalarında müşteri memnuniyeti. Dumlupınar Üniversitesi, Yayımlanmamış Yüksek Lisans Tezi, Kütahya.

http://www.tkbb.org.tr/tarihce (Erişim Tarihi: 27.06.2018). 